\title{
Inhibition of Protein Synthesis by D-threo-chloramphenicol in the Laboratory and Nodule Forms of Rhizobium lupini
}

\author{
By D. R. COVENTRY AND M. J. DILWORTH* \\ Department of Soil Science and Plant Nutrition, Institute of Agriculture, \\ University of Western Australia, Nedlands, Western Australia 6009
}

(Received 30 December 1974; revised 20 March 1975)

SUMMARY

\begin{abstract}
Protein synthesis by both laboratory-grown bacteria and isolated nodule bacteroids of Rhizobium lupini (strain wU8) is inhibited by D-threo-chloramphenicol, the bacteroid form being the more sensitive to the antibiotic. A comparison between the two forms of the uptake of $\left[{ }^{14} \mathrm{C}\right]$ chloramphenicol showed that the bacteria always attained a lower intracellular chloramphenicol concentration. It is proposed that the sensitivity difference is due to a difference in membrane permeability between the two forms.
\end{abstract}

\section{INTRODUCTION}

The free-living form (bacterium) of rhizobia is a non- $\mathrm{N}_{2}$-fixing organism indistinguishable from those grown in the laboratory. The root nodule-inhabiting form (bacteroid) possesses the $\mathrm{N}_{2}$-fixing enzyme system and appears to be capable of only limited division, but is usually much larger than the bacterium and often changed in shape. These forms might differ in bacterial wall and membranes and these differences might play important roles in the effective maintenance of the $\mathrm{N}_{2}$-fixing association. However, little is known about rhizobial walls or membranes after the transition of the bacterial form into the $\mathrm{N}_{2}$-fixing bacteroid.

Viomycin-resistant mutants of Rhizobium meliloti (Jordan, Yamamura \& McKague, 1969; MacKenzie \& Jordan, 1970, 1972) are ineffective in symbiotic $\mathrm{N}_{2}$-fixation whereas the viomycin-sensitive parent strain is effective. Cell-free protein synthesis by both strains is inhibited by viomycin, indicating that the viomycin resistance is most probably due to a change in membrane permeability (Alexander, Jordan \& McKague, 1969). Changes in the phospholipid composition of the membrane correlate with resistance to viomycin (MacKenzie \& Jordan, I970, 1972). Differences between bacterial and bacteroid walls are seen in localized weaknesses in bacteroid walls (Jordan, Grinyer \& Coulter, 1963), wall surface differences as revealed by freeze-etching (MacKenzie, Vail \& Jordan, 1973) and differing behaviour after osmotic shock (van Brussel, 1973).

Glucose is neither taken up nor respired by bacteroids ( $R$. lupini, strain wU8) until after a 5 to $6 \mathrm{~h} \mathrm{lag}$; however, a washing of the respiring bacteroids removed the ability to further respire glucose (Kidby, 1967). The addition of 0.1 mM-chloramphenicol prevented any glucose utilization. Kidby suggests that the extensive washing required to separate the bacteroids from their legume host may have inactivated a bacteroid wall permease respon-

\footnotetext{
* Present address: School of Environmental and Life Sciences, Murdoch University, Murdoch, Western Australia 6153.
} 
sible for glucose transport. Bergersen \& Turner (1967) have also reported a setback to bacteroid metabolism after the washing of bacteroids in a medium of low osmotic pressure.

Chloramphenicol inhibition of glucose utilization by bacteroids is of further interest because Graham (1963) reported that agar plate tests with chloramphenicol-impregnated discs revealed no sensitivity to chloramphenicol of laboratory cultures of $R$. lupini (strain wU8). Hence this study was undertaken to establish if a difference exists between laboratorygrown bacteria and isolated nodule bacteroids of $R$. lupini, strain wU8, in their ability to synthesize protein in the presence of chloramphenicol. If a difference does exist then this may be due to a permeability difference between the two forms.

\section{METHODS}

Organisms and media. Rhizobium lupini, strain wu8, was grown in broth culture (Godfrey $\&$ Dilworth, 197I). The bacteria were harvested by centrifugation at $5000 \mathrm{~g}$ for $20 \mathrm{~min}$, and were washed once in $0 . \mathrm{I}$ M-potassium phosphate buffer $\mathrm{pH} 6.8$ before use.

Yellow lupin (Lupinus luteus L. var Weico III) was inoculated with strain wu8, and grown as described by Dilworth (1969). Intact plants were harvested before flowering, and their roots immersed in acidified mercuric chloride $(0 . \mathrm{I} \%, \mathrm{w} / \mathrm{v})$ for $6 \mathrm{~min}$. The roots were then washed in six changes of sterile water before the nodules were removed. The nodules were crushed in a mortar in five times their weight of 0.1 M-potassium phosphate buffer pH 6.8. The homogenate was squeezed through Miracloth (Calbiochem) and the filtrate was centrifuged at $10000 \mathrm{~g}$ for $20 \mathrm{~min}$. The resulting bacteroid pellet was twice suspended and centrifuged in $0.1 \mathrm{M}$-potassium phosphate buffer $\mathrm{pH} 6.8$ before being resuspended for use.

All glassware, centrifuge tubes, instruments and phosphate buffer were sterilized either by autoclaving or by dry heat treatment. The incubation media were sterilized by passage through $0.22 \mu \mathrm{m}$ Millipore filters.

Incubation with $\left[{ }^{3} \mathrm{H}\right]$ leucine. Suspended rhizobia were incubated in $6 \mathrm{ml}$ volumes of a control medium ( $25 \mathrm{mM}-\mathrm{KCl} ; 5 \mathrm{mM}-\mathrm{Mg}(\mathrm{Ac}){ }_{2}$; I $50 \mu \mathrm{M}-\mathrm{ATP} ; 50 \mu \mathrm{M}-\mathrm{GTP} ; 25$ mM-sodium succinate; $45 \mathrm{mM}$-potassium phosphate buffer $\mathrm{pH} 6.8 ; 70 \mu \mathrm{M}$-leucine; I50 $\mu \mathrm{M}$ each of the other 19 amino acids; I $\mu \mathrm{Ci} \mathrm{L-4,5}-\left[{ }^{3} \mathrm{H}\right]$ leucine, specific activity $2 \cdot 4 \mathrm{mCi} / \mathrm{mmol}$ ). Rhizobia were also incubated in test media which differed from the control medium only by the inclusion of varying concentrations of antibiotics. Incubation was in flasks in a shaking water bath at $28{ }^{\circ} \mathrm{C}$ for the required times.

After incubation, $0.5 \mathrm{ml}$ volumes of rhizobial suspensions were withdrawn, disrupted by sonication at $9 \mathrm{kHz}$ for $\mathrm{I} 5 \mathrm{~min}$ at $0{ }^{\circ} \mathrm{C}$ in a Raytheon sonicator, and the suspensions centrifuged at $12000 \mathrm{~g}$. An equal volume of $5 \%(\mathrm{w} / \mathrm{v})$ trichloroacetic acid (TCA) was added to the supernatant liquid and the resulting precipitate was washed twice with $5 \%(\mathrm{w} / \mathrm{v})$ TCA and then incubated at $90{ }^{\circ} \mathrm{C}$ for $15 \mathrm{~min}$ in $5 \%(\mathrm{w} / \mathrm{v})$ TCA. The precipitate was washed with absolute ethanol before being dissolved in I M-hyamine hydroxide.

Uptake of $\mathrm{D}-$ threo- $\left[{ }^{14} \mathrm{C}\right]$ chloramphenicol. Media without $\mathrm{L}-4,5-\left[{ }^{3} \mathrm{H}\right]$ leucine were supplemented with $\mathrm{D}$-threo-chloramphenicol $\left(\left[\mathrm{I}-{ }^{14} \mathrm{C}\right]\right.$ dichloroacetyl) to known concentrations. Samples $(2.5 \mathrm{ml})$ were withdrawn at intervals and immediately centrifuged at $1000 \mathrm{~g}$ for $20 \mathrm{~min}$, and the rhizobia resuspended in a solution of $0.3 \mathrm{M}$-sucrose containing the appropriate concentration of chloramphenicol. The rhizobia were twice suspended and centrifuged in this sucrose solution before being resuspended in a Triton X-based scintillant cocktail for radioactivity determinations (Godfrey \& Dilworth, 197I).

Counting. A $0 \cdot \mathrm{I} \mathrm{ml}$ volume was withdrawn from each flask and with appropriate dilutions the rhizobia were counted under dark-field illumination in a Hawksely-Thoma counting 
chamber. Further samples were withdrawn from the bacterial suspensions at zero time, and from the bacteroid suspensions after 0,7 and $13 \mathrm{~h}$ incubation periods. Viable counts from these samplings were performed by the drop method of Miles \& Misra (1938) on partly-dry plates of $\mathrm{YM}_{3}+\mathrm{P}$ agar (Godfrey \& Dilworth, I97I). The plates were incubated at $28^{\circ} \mathrm{C}$ for $24 \mathrm{~h}$ and counts made of colonies of fast-growing contaminating organisms. Strain wU8 is a slow-growing rhizobium whose colonies do not appear until after 7 to 8 days' incubation.

Electron microscopy. Parlodion carbon grids were floated on bacterial and bacteroid suspensions for $2 \mathrm{~min}$. The grids were air-dried before refloating on $2 \%(\mathrm{w} / \mathrm{v})$ tungstophosphoric acid for $2 \mathrm{~min}$. The negatively-stained rhizobia were viewed at a magnification of $\times 5000$ using a Hitachi HU I I B electron microscope. Approximately 200 of each rhizobial form were photographed for the calculation of rhizobial volumes. As $R$. lupini bacteroids are only slightly changed in appearance and size when compared with the laboratory-grown rhizobia, the volumes of both rhizobial forms were calculated by assuming that the rhizobia were cylinders with a hemisphere at each end.

Analytical procedures and reagents. Soluble protein was determined by the Lowry reaction (Lowry et al. 195I) using bovine serum albumin as a standard. Protein samples solubilized in hyamine hydroxide were counted in a toluene $(0.5 \%$, w/v)-PPO $(0.03 \%$, w/v)-POPOP scintillant cocktail on a Packard 3320 Tri Carb counter. Disintegrations per minute were calculated from the scintillation counts and the counting efficiency as determined by internal standards.

$\mathrm{L}-4,5-\left[{ }^{3} \mathrm{H}\right]$ leucine and D-threo-chloramphenicol $\left(\left[\mathrm{I}-{ }^{14} \mathrm{C}\right]\right.$ dichloroacetyl) were supplied by the Radiochemical Centre, Amersham, Buckinghamshire. D-threo-Chloramphenicol was obtained from Parke-Davis and Co., erythromycin from Abbott Australasia Pty Ltd and lincomycin from The Upjohn Co. All reagents were of analytical grade.

\section{RESULTS}

\section{Contaminating organisms}

Studies of the metabolism of bacteroids are hampered by the difficulty in isolating bacteroids relatively free from fast-growing contaminating organisms, as it is very difficult to produce legume seedlings which are bacteria free (Evans, Campbell \& Hill, 1971). Therefore care was taken to minimize the numbers of contaminating bacteria and to monitor the numbers of these bacteria throughout the incubation periods. The upper limits of contaminant populations reached are shown in Table I.

The use of a blender for homogenizing the lupin nodules greatly increased the contaminants in the resultant bacteroid suspensions. This procedure macerated the cortical tissue and the increased contamination was probably due to the release of intercellular cortical bacteria. The much gentler grinding with a pestle and mortar was therefore employed.

The need for complete sterility has been stressed for the unequivocal demonstration of protein synthesis by isolated plasmids (Davies \& Cocking, 1967) and isolated mitochondria (Beattie, Basford \& Koritz, 1967). Contaminants were present in the bacteroid suspensions used (Table I) but we do not consider that they were responsible for the protein synthesis observed. Although bacteroids do not reproduce, increases in protein per bacteroid have been recorded during the development of the same strain isolated from lupin nodules (Dilworth \& Williams, 1967), and the examination of a variety of contaminant bacteria under the light microscope showed them to be uniformly small organisms. Caution has to be observed with comparisons of calculated protein synthesis by the contaminants and the observed $\left[{ }^{3} \mathrm{H}\right]$ leucine incorporation into cellular protein, but the incorporation reported in 


\section{Table I. Upper limits of bacterial contaminants}

The results are the upper limits of bacterial contaminants observed during five separate experiments with chloramphenicol in the test medium (CAP) and two experiments with erythromycin (Ery). Rhizobia and contaminants were counted as described in Methods.

$\begin{array}{llccc}\begin{array}{c}\text { Incubation } \\ \text { medium }\end{array} & \begin{array}{c}\text { Rhizobium } \\ \text { form }\end{array} & \begin{array}{c}\text { Rhizobia/ml } \\ \text { medium }\end{array} & \begin{array}{c}\text { Time after } \\ \text { rhizobium } \\ \text { inoculation } \\ \text { (h) }\end{array} & \begin{array}{c}\text { Contaminants } / \mathrm{ml} \\ \text { medium }\end{array} \\ \text { Control } & \text { Bacteroid } & 10^{10} & 0 & 10^{4} \\ \text { Control } & \text { Bacteroid } & 10^{10} & 7 & 5 \times 10^{4} \\ \text { Control } & \text { Bacteroid } & 10^{10} & 13 & 4 \times 10^{6} \\ \text { CAP (O.I mM) } & \text { Bacteroid } & 10^{10} & 13 & 5 \times 10^{4} \\ \text { Ery (O. I mM) } & \text { Bacteroid } & 10^{10} & 13 & 5 \times 10^{4} \\ \text { Control } & \text { Bacterial } & 10^{10} & 0 & 0\end{array}$

this paper does not appear to correspond with that possible by contaminants. In addition, a concentration of erythromycin which reduced contaminant numbers by $99 \%$ had no effect on $\left[{ }^{3} \mathrm{H}\right]$ leucine incorporation. Finally, autoradiography of the suspensions revealed the expected numbers of silver grains associated with the bacteroids.

\section{Inhibitory effects of antibiotics}

Incubation of both bacteroids and bacteria in the presence of $0.1 \mathrm{mM}$ D-threo-chloramphenicol inhibited protein synthesis (Fig. I $a$ ). The 5 to $6 \mathrm{~h}$ lag before the commencement of bacteroid protein synthesis is of the same order of magnitude as the lag obtained before isolated bacteroids (strain wU8) could utilize sugars for respiration (Kidby, 1967). Since succinate is rapidly respired by bacteroids (Tuzimura \& Meguro, 1960; Kidby, 1967) it is assumed that the bacteroids were not suffering from a lack of ATP for protein synthesis. The failure by Graham (I963) to demonstrate growth inhibition of $R$. lupini by chloramphenicol sensitivity discs was probably due to the method used: growth of $R$. lupini would barely have commenced before chloramphenicol would have diffused to a concentration which was no longer inhibitory to growth.

The inhibitory effects of chloramphenicol on protein synthesis by the two rhizobial forms differed (Fig. I $b$ ), with the bacteroids exhibiting greater sensitivity to chloramphenicol. Erythromycin and lincomycin showed a similar difference of inhibitory effect (Table 2). Incubation of bacteroids in a I mM solution of L-threo-chloramphenicol gave no inhibition of protein synthesis.

\section{Permeability differences}

To investigate if the sensitivity differences obtained between the rhizobial forms were due to a change in permeability of the bacteroid membrane, the suspended rhizobia were incubated with increasing concentrations of $\mathrm{D}$-threo- $\left[{ }^{[4} \mathrm{C}\right]$ chloramphenicol. Concurrently, bacteroids were incubated in solutions to which the D-threo- $\left[{ }^{14} \mathrm{C}\right]$ chloramphenicol was not introduced until after $7 \mathrm{~h}$ of incubation.

The bacteroids attained an intracellular concentration of chloramphenicol identical with that of the incubation medium, whereas the laboratory-grown bacteria resisted to some extent the entry of chloramphenicol (Fig. 2). This would appear to indicate a permeability difference between the two rhizobium forms. However, the bacteroids which were exposed to $\left[{ }^{14} \mathrm{C}\right]$ chloramphenicol after $7 \mathrm{~h}$ incubation, attained an intracellular chloramphenicol concentration different from that of the bacteroids exposed to $\left[{ }^{14} \mathrm{C}\right]$ chloramphenicol at the 

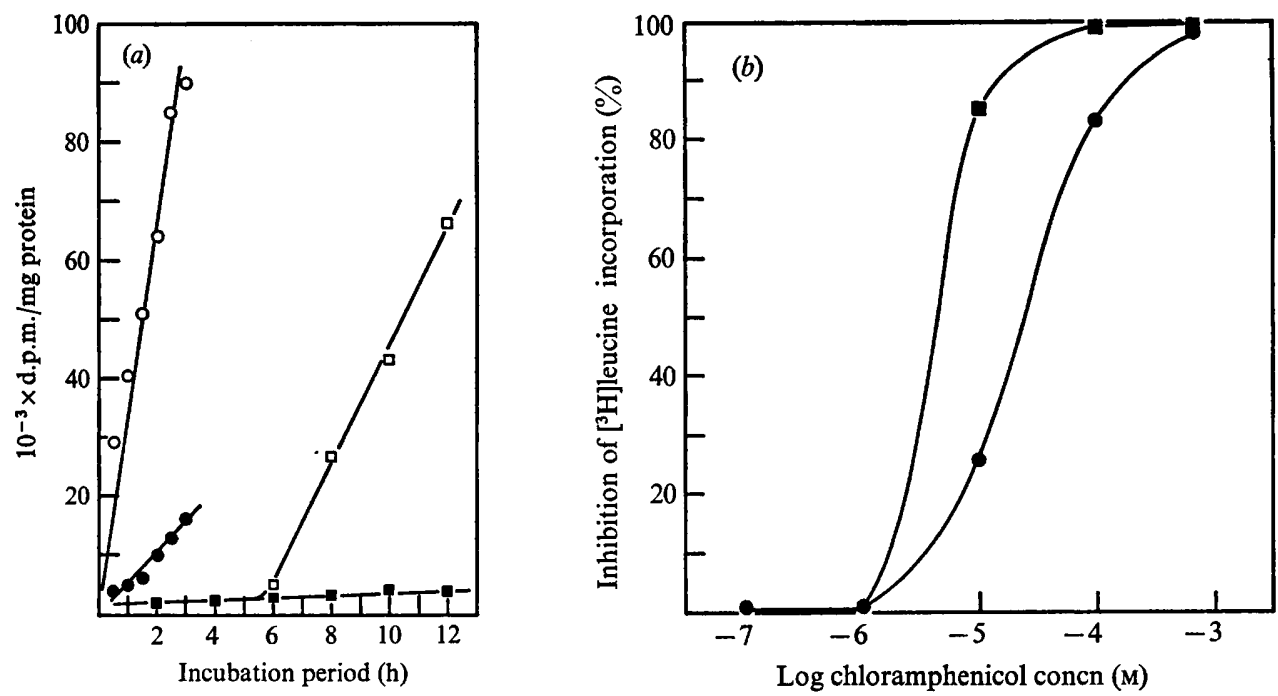

Fig. I. (a) The time course, and (b) comparison of the effects of chloramphenicol concentration, on the incorporation of $4,5-\left[{ }^{3} \mathrm{H}\right]$ leucine into TCA-insoluble rhizobia protein. The protein contents were: bacteroids, $0.50 \pm 0.10 \mathrm{mg} / \mathrm{ml}$; bacteria, $0.18 \pm 0.08 \mathrm{mg} / \mathrm{ml}$. The conditions of incubation are detailed in Methods. (a) $\bigcirc$, Bacteria, control incubation medium; 0 , bacteria, $0 \cdot 1 \mathrm{mM}$-chloramphenicol medium; $\square$, bacteroids, control medium; $\mathbf{a}$, bacteroids, $0 . \mathrm{I}$ mM-chloramphenicol medium. (b) $\square$, Bacteroids; 0, bacteria. The curves are constructed from two separate experiments, the rhizobia being harvested after two incubation times.

Table 2. The effect of erythromycin, lincomycin and L-threo-chloramphenicol on incorporation of $4,5-\left[{ }^{3} \mathrm{H}\right]$ leucine into TCA-insoluble protein by rhizobia

The incubation media were varied from the control medium described in Methods by additions of erythromycin (Ery), lincomycin (Linco) and L-threo-chloramphenicol (L-CAP). The conditions of incubation are detailed in Methods.

Treatment
Control
Ery (I mM)
Linco (I mM)
Control
Ery ( $\mathrm{mM})$
Ery (o. I mM)
Linco ( $\mathrm{mM})$
Linco (o. I mM)
L-CAP (I mM)

$\begin{array}{cc}\text { Rhizobium form } & \begin{array}{c}{\left[{ }^{3} \mathrm{H}\right] \text { leucine }} \\ \text { incorporation } \\ \text { (\% inhibition) }\end{array} \\ \text { Bacterial } & \circ \\ \text { Bacterial } & 79 \\ \text { Bacterial } & 0 \\ \text { Bacteroid } & 0 \\ \text { Bacteroid } & 95 \\ \text { Bacteroid } & 0 \\ \text { Bacteroid } & 4 \mathrm{I} \\ \text { Bacteroid } & \circ \\ \text { Bacteroid } & 0\end{array}$

$\left[{ }^{3} \mathrm{H}\right]$ leucine incorporation

commencement of incubation (Fig. 2). These bacteroids exhibited altered behaviour to the entry of chloramphenicol but still had a greater intracellular chloramphenicol concentration than the laboratory-grown bacteria.

\section{DISCUSSION}

The results show that protein synthesis in laboratory-grown bacteria and isolated nodule bacteroids of $R$. lupini was inhibited by chloramphenicol, with the bacteroid form being the more sensitive. Although the bacteroids recovered some resistance to the entry of chloramphenicol, the observation that they still attained a greater intracellular chloramphenicol 


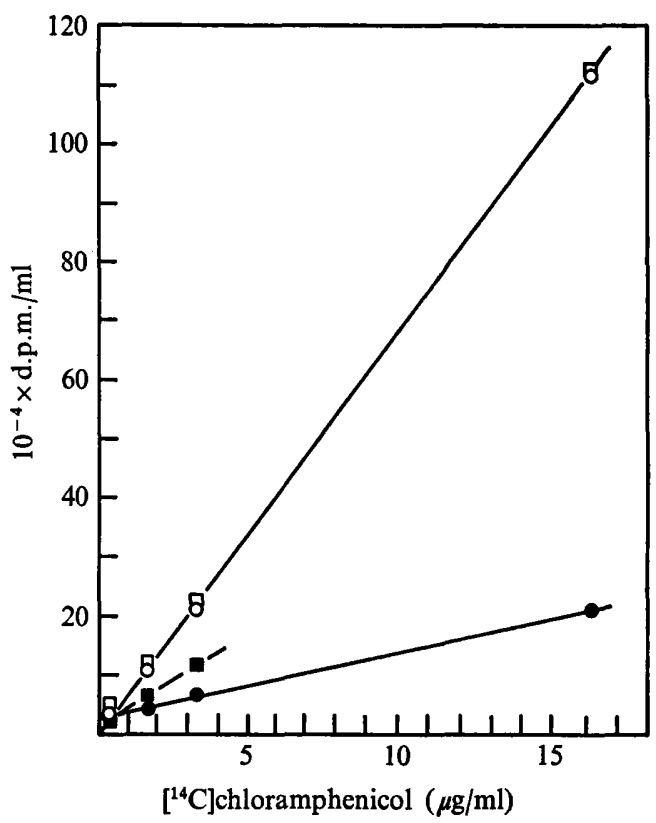

Fig. 2. The uptake of $\mathrm{D}$-threo-chloramphenicol $\left(\left[\mathrm{I}-{ }^{14} \mathrm{C}\right]\right.$ dichloroacetyl) by rhizobia. $O$, Standard curve; $\boldsymbol{O}$, bacteria; $\square$, bacteroids exposed to $\left[{ }^{14} \mathrm{C}\right]$ chloramphenicol at start of incubation; $\boldsymbol{\square}$, bacteroids exposed to $\left[{ }^{14} \mathrm{C}\right] \mathrm{chloramphenicol}$ after $7 \cdot 0 \mathrm{~h}$ incubation. The standard curve represents the d.p.m./ml contained in each incubation medium. Portions (I, 5, 10 and $50 \mu \mathrm{l})$ of D-threochloramphenicol ([I- $\left.{ }^{14} \mathrm{C}\right]$ dichloroacetyl), specific activity $27 \cdot 3 \mathrm{mCi} / \mathrm{mg}$ and $\mathrm{I} \cdot 94 \mathrm{mg} / \mathrm{ml}$, were added to each medium in a final volume of $6.0 \mathrm{ml}$. The rhizobium curves represent the d.p.m./ml of pooled rhizobium volume. The volumes were determined as described in Methods. The bacteria had a volume of $7.5 \pm 2.3 \times 10^{-13} \mathrm{ml} /$ bacterium, and the bacteroids a volume of $5.0 \pm \mathrm{I} \cdot 7 \times 10^{-12} \mathrm{ml} / \mathrm{bacteroid}$. The volumes of both rhizobia forms exhibited a normal frequency distribution with a slight positive skew. The rhizobia harvest and radioactivity count procedure were as described in Methods. Duplicate rhizobia samples were harvested at the following times after commencement of incubation: $\mathrm{I} \cdot 5$ and $3.0 \mathrm{~h} ; \square, \mathrm{I} \cdot 5,3.0,10.0$ and $\mathrm{I} 4.0 \mathrm{~h} ; \mathrm{\square}, 9.5$ and $2.0 \mathrm{~h}$. The slopes are significantly different from each other at the $0.1 \%$ probability level $(\square, \mathbf{\square} ; \square, 0$ ), and the $0.5 \%$ probability level $(\mathbf{a}, \mathbf{0})$.

concentration than the laboratory-grown bacteria would indicate an altered permeability. This permeability difference may not necessarily be present in the nodule. If permeability differences do exist then they are likely to be important in the maintenance of the legumerhizobium symbiosis.

In situ, bacteroids (or small groups of bacteroids) are surrounded by a plant membrane within the cytoplasm of the central nodule tissue (Dart \& Mercer, I963; Jordan et al. 1963; Kidby \& Goodchild, I966). The success of the rhizobium is therefore dependent on the interactions between the two symbiotic partners, with the host cell providing the environment in which the bacterial form can change to the $\mathrm{N}_{2}$-fixing form. The bacteroids, once formed, are further dependent on the host for the supply of photosynthetic products as substrates for their metabolism (Bergersen, 197I), and at the same time the products of $\mathrm{N}_{2}$ reduction are being exported from the nodule (Dilworth, 1974). An altered membrane permeability may be beneficial to both the bacteroid and legume host by facilitating a more rapid exchange of substrates and $\mathrm{N}_{2}$-fixation products. 
We thank Mr T. M. Armitage of this department for his assistance with the electron microscopy. The L-isomer of chloramphenicol was supplied by $\mathrm{Dr}$ H. M. Crooks, Parke Davis \& Co., Ann Arbor, Michigan, U.S.A. The financial support of the Wheat Industry Research Council of Australia in the form of a post-graduate studentship to one of us (D.R.C.) is gratefully acknowledged.

\section{REFERENCES}

AleXander, D. C., Jordan, D. C. \& McKague, M. (1969). Inhibition by viomycin of the cell-free protein synthesis in sensitive and resistant strains of Rhizobium meliloti. Canadian Journal of Biochemistry 47, I092-I094.

BeATtIE, D. S., BASFoRd, R. E. \& KorITZ, S. B. (1967). Bacterial contamination and amino acid incorporation by isolated mitochondria. Journal of Biological Chemistry 242, 3366-3368.

Bergersen, F. J. (1971). Biochemistry of symbiotic nitrogen fixation in legumes. Annual Review of Plant Physiology 22, I2 I-140.

Bergersen, F. J. \& TURNER, G. L. (1967). Nitrogen fixation by the bacteroid fraction of breis of soybean root nodules. Biochimica et biophysica acta 14I, 507-5I 5 .

VAN BRUSSEL, A. A. N. (1973). The cell wall of bacteroids of Rhizobium leguminosarum Frank. Ph.D. thesis, University of Leiden.

DART, P. J. \& MERCER, F. V. (1963). Membrane envelopes of legume bacteroids. Journal of Bacteriology 85 , $95 \mathrm{I}-952$.

Davies, J. W. \& Cocking, E. C. (1967). Protein synthesis in tomato-fruit locule tissue: incorporation of amino acids into protein by aseptic cell-free systems. Biochemical Journal ro4, 23-33.

DiLWorth, M. J. (1969). The plant as the genetic determinant of leghaemoglobin production in the legume root nodule. Biochimica et biophysica acta 184, 432-44I.

Dilworth, M. J. (1974). Dinitrogen fixation. Annual Review of Plant Physiology 25, 8I-I 14.

Dilworth, M. J. \& Williams, D. C. (1967). Nucleic acid changes in bacteroids of Rhizobium lupini during nodule development. Journal of General Microbiology 48, 3I-36.

Evans, H. J., CampBell, N. E. R. \& Hill, S. (197I). Asymbiotic nitrogen-fixing bacteria from the surfaces of nodules and roots of legumes. Canadian Journal of Microbiology 18, 13-2I.

Godfrey, C. A. \& DilworTH, M. J. (I97I). Haem biosynthesis from $\left[{ }^{14} \mathrm{C}\right]-\delta$-aminolaevulinic acid in laboratory-grown and root nodule Rhizobium lupini. Journal of General Microbiology 69, 385-390.

Graham, P. H. (1963). Antibiotic sensitivities of the root nodule bacteria. Australian Journal of Biological Sciences 16, 557-559.

KIDBY, D. K. (1967). Carbon metabolism in legume root nodules. Ph.D. thesis, University of Western Australia.

KIDBY, D. K. \& GooDCHILD, D. J. (1966). Host influence on the ultrastructure of root nodules of Lupinus luteus and Ornithopus sativus. Journal of General Microbiology 45, I47-I 52.

Jordan, D. C., GrinYeR, I. \& Coulter, W. J. (I963). Electron microscopy of infection threads and bacteria in young nodules of Medicago sativa. Journal of Bacteriology 86, 125-137.

Jordan, D. C., Yamamura, Y. \& McKague, M. E. (1969). Mode of action of viomycin on Rhizobium meliloti. Canadian Journal of Microbiology 15, 1005-1012.

Lowry, O. H., Rosebrough, N. J., FarR, A. L. \& Randall, R. J. (195I). Protein measurement with the Folin phenol reagent. Journal of Biological Chemistry 193, 265-275.

MACKenzIE, C. R. \& JoRDAN, D. C. (1970). Cell wall phospholipid and viomycin resistance in Rhizobium meliloti. Biochemical and Biophysical Research Communications 40, 1008-101 2.

MACKeNZIE, C. R. \& JoRDAN, D. C. (1972). Cell wall composition and viomycin resistance in Rhizobium meliloti. Canadian Journal of Microbiology 18, I168-1 170.

MACKeNZIE, C. R., VAIL, W. J. \& JORDAN, D. C. (1973). Ultrastructure of free-living and nitrogen fixing forms of Rhizobium meliloti as revealed by freeze etching. Journal of Bacteriology Ir3, 387-393.

Miles, A. A. \& MisRA, S. S. (1938). The estimation of bactericidal power of blood. Journal of Hygiene 38, $732-749$.

Tuzimura, K. \& Meguro, H. (1960). Respiration substrate of Rhizobium in the nodules. Journal of Biochemistry 47, 391-397. 